\title{
СОЦІАЛЬНО-ЕКОНОМІЧНА ХАРАКТЕРИСТИКА ОСІБ 3 ІНВАЛІДНІСТЮ ПІСЛЯ ТРАВМ ОПОРНО-РУХОВОГО АПАРАТУ
}

\author{
Івано-Франківський національний медичний університет, м. Івано-Франківськ, Україна
}

\begin{abstract}
Мета: проаналізувати соціально-економічні характеристики осіб з інвалідністю після травм опорно-рухового апарату.

Матеріали і методи. Проведено медико-соціальне дослідження на базі Івано-Франківського бюро медикосоціальної експертизи. За спеціально розробленою авторською програмою опитали репрезентативну вибірку із 150 осіб, які проходили переосвідчення у зв'язку з інвалідністю після травм опорно-рухового апарату. Статистичну обробку отриманого матеріалу здійснювали шляхом розрахунку частоти поширення чинників на 100 опитаних і стандартної похибки $( \pm m)$ для відносних величин, а оцінку достовірності різниці даних у групах порівняння та перевірку нульової гіпотези проводили шляхом розрахунку критерію відповідності хі-квадрат $\left(x^{2}\right)$ Пірсона. Використано методи: епідеміологічний, соціологічний, медико-статистичний.

Результати. Встановлено, що найчастіше внаслідок травм опорно-рухового апарату призначали III групу інвалідності - $(75,5 \pm 3,5) \%$, II групу - $(22,5 \pm 3,4) \%$, а I - $(2,0 \pm 1,1)$ \%. Ї̈̈ причинами були переломи кісток нижніх $((40,7 \pm 4,0) \%)$ та верхніх $((18,7 \pm 3,2) \%)$ кінцівок, травми хребта $((20,0 \pm 3,3) \%)$, травматична ампутація ділянок тіла $((11,3 \pm 2,6) \%)$, множинні переломи $((6,0 \pm 1,9) \%)$ та термічні чи хімічні опіки $((3,3 \pm 1,5) \%)$. Майже всі опитані працездатного віку: до 30 років - 7,3 \%, 30-39 років - 31,1 \%, 40-49 років - 30,5 \%, 50-59 років - 30,5 \%, 60 і старші $0,7 \%$. 3'ясовано, що найбільш вразливими щодо інвалідності після травм опорно-рухового апарату є чоловіки (69,5 \%), мешканці сільської місцевості (64,9 \%), зайняті у професіях із фрізичним характером праці $(66,3-65,7$ \%). Виявлено, що наявність інвалідності після травм опорно-рухового апарату призводить до суттєвого погіршення матеріального добробуту в $(51,0 \pm 4,1)$ \% таких осіб, більш виражено серед мешканців села $((61,2 \pm 4,9) \%)$, що тільки частково покривається матеріальною допомогою у межах системи соціального захисту $((43,5 \pm 7,3) \%)$. Показано, що інвалідність після травм опорно-рухового апарату та пов'язане із нею погіршення стану здоров'я $((87,4 \pm 3,0) \%)$ супроводжується втратою $((51,7 \pm 4,1) \%)$ чи зміною $((27,8 \pm 3,6) \%)$, а також пошуком $((41,7 \pm 4,0) \%)$ місця роботи, також більш акцентовано серед чоловіків із сільських місцевостей.

Висновки. Необхідно удосконалити систему реабілітації осіб з інвалідністю після травм опорно-рухового апарату, зокрема серед чоловіків, зайнятих у сільському господарстві на роботах із фрізичним характером праці.
\end{abstract}

КЛЮчОВІ СЛОВА: організація охорони здоров'я; інвалідність; реабілітація; соціально-економічні чинники.

Проблема інвалідності та реабілітації осіб 3 інвалідністю не втрачає своєї актуальності ось уже багато років поспіль. Так, за даними ВООЗ, кількість осіб з інвалідністю у світі складає більше 1 мільярда осіб, а це близько $15 \%$, з яких майже 200 мільйонів мають серйозні труднощі у фрункціонуванні. I, за прогнозами експертів, у майбутньому їх чисельність буде тільки збільшуватися $[2,7,10,12]$.

В Україні кількість осіб як з уродженою, так і 3 набутою інвалідністю залишається відносно сталою, проте за рахунок зменшення чисельності населення зростає частка таких людей в популяції. За даними Центру перспективних соціальних досліджень Міністерства соціальної політики України та НАН України, на початку 2020 р. зареєстровано 2,7 мільйона осіб, які мають статус людини 3 інвалідністю, що становить 6,4 \% від загальної кількості населення. Для порівняння: в 2011 р. кількість таких осіб становила 2,7 мільйона (5,9 \%), у 2015 р. - 2,8 мільйона (6,1 \%) [6].

(с) О. З. Децик, Г. Я. Юкіш, 2020
Водночас через складну процедуру експертизи рівень інвалідності населення суттєво менший за відповідний європейський показник, який перевищує $10 \%$ [3].

Серед першопричин інвалідності населення, поряд із такими хронічними захворюваннями, як серцево-судинні та злоякісні новоутворення, стабільно третє місце займає травматизм, соціально-економічне значення якого посилюється тим, що він уражає переважно осіб працездатного віку, вимагає довготривалого лікування та реабілітації $[2,7,10,12]$.

Загалом проблема інвалідності має соціальний характер і не існує суспільства, яке б вона оминула, а рівень її вирішення залежить від економічного, політичного, соціального та культурного розвитку держави $[1,4,8]$.

У статті 1 Закону України «Про реабілітацію осіб з інвалідністю в Україні» від 6 жовтня 2005 р. зазначено: «اнвалідність - це міра втрати здоров'я у зв'язку із захворюванням, травмою (ії наслідками) або уродженими вадами, що при взаємодії 
із навколишнім середовищем може призводити до обмеження життєдіяльності особи, внаслідок чого держава зобов'язана створити умови для реалізації нею прав нарівні 3 іншими громадянами та забезпечити її соціальний захист» [5].

У цьому напрямі 16 грудня 2009 р. Верховна Рада України ратифрікувала Конвенцію про права осіб 3 інвалідністю, у якій окреслено кроки, що мали б зробити держави для забезпечення прав людей 3 інвалідністю, та акцентовано увагу на тому, що інвалідність існує у суспільстві, а не в особі та повинна розглядатися як результат взаємодії між особою та її оточенням [11].

у 2011 р. Всесвітньою організацією охорони здоров'я та Світовим банком була опублікована Всесвітня доповідь щодо інвалідності [13], в якій наголошується, що держави повинні послідовно долати основні соціальні перешкоди, що стають на заваді особам 3 інвалідністю, серед яких основними $€$ неадекватні заходи політики і стандарти, нестача послуг, проблеми 3 наданням послуг внаслідок недостатнього кадрового забезпечення та фрінансування, низька доступність, неадекватна інорормація і комунікація, відсутність консультування та включення в суспільне життя, відсутність даних і досвіду.

Зрозуміло, що для прийняття належних управлінських рішень та політик у напрямі подолання цих бар'єрів і побудови ефективної системи реабілітаційних заходів у державі необхідно, в першу чергу, володіти належною інформацією, у тому числі про соціально-економічний статус осіб з інвалідністю.

Мета дослідження: проаналізувати соціально-економічні характеристики осіб з інвалідністю після травм опорно-рухового апарату.

Матеріали і методи. Проведено медикосоціальне дослідження репрезентативної вибірки 150 осіб з інвалідністю після травм опорнорухового апарату за спеціально розробленою авторською програмою.

Збір даних здійснювали впродовж 2018 р. на базі Івано-Франківського бюро медико-соціальної експертизи, яке було обрано як наукова база дослідження. Відбір обстежених проводили випадковим методом.

Опитування для об'єктивізації даних було анонімним (за бажанням пацієнта) і проводили у момент чергового переосвідчення осіб з інвалідністю.

Розробку отриманого матеріалу здійснювали шляхом формування баз даних на основі Microsoft Excel, де матеріали групували за місцем проживання (міські, сільські мешканці), статтю (чоловіки, жінки) та віком (до 30 років, 30-39, 40-49, 50-59, 60 років і старші).

Статистичну обробку отриманого матеріалу проводили шляхом розрахунку частоти поширення чинників на 100 опитаних і стандартної по- хибки ( $\pm m)$ для відносних величин, а оцінку достовірності різниці даних у групах порівняння та перевірку нульової гіпотези здійснювали шляхом розрахунку критерію відповідності хі-квадрат $\left(\mathrm{X}^{2}\right)$ Пірсона [9].

Використано методи: епідеміологічний, соціологічний, медико-статистичний.

Результати дослідження та їх обговорення. Оскільки контингентом дослідження були особи, які проходили переосвідчення на предмет стійкої непрацездатності, то зрозуміло, що це, в основному - особи працездатного віку. Зокрема, приблизно одинакові частки обстежених припадали на вікові категорії 30-39 років (31,1 \%), 40-49 років (30,5 \%) та 50-59 років (30,5\%). Значно менше серед опитаних було осіб віком до 30 років (7,3 \%) і поодинокі випадки - осіб, старших 60 років (0,7 \%), що пояснюється особливістю пенсійного законодавства.

Поділ обстежених за статтю підтвердив, що травматизм частіше спостерігають, а відповідно призводить до інвалідності, у чоловіків, оскільки їх частка серед опитаних більш як удвічі перевищувала частку жінок - 69,5 \% проти 30,5 \% $(p<0,001)$.

Опитані особи найчастіше були представлені мешканцями передгірських районів (47,6 \%), ще третина (28,0 \%) проживала у рівнинній місцевості та майже стільки ж (24,5 \%) - у гірській, що загалом відображає аналогічний поділ населення Івано-Франківської області.

Разом із тим, привертає увагу, що серед обстежених удвічі більше мешканців сільських поселень, ніж міських (64,9 \% проти 35,1 \%, p<0,001), що може вказувати як на вищу травматогенність сільського укладу життя, так і на нижчу доступність сільських мешканців до сучасних медикореабілітаційних технологій.

Встановлено, що найчастіше під час переосвідчення, незалежно від віку, статі та місця проживання ( $>0,05)$, респондентам призначали III групу інвалідності - $(75,5 \pm 3,5) \%$, ще у чверті випадків $(22,5 \pm 3,4) \%$ - II групу та лише $(2,0 \pm 1,1) \%$ - I групу.

Виявлено, що основними причинами інвалідності опорно-рухового апарату були (рис. 1) переломи кісток кінцівок - нижніх $((40,7 \pm 4,0) \%)$ та верхніх $((18,7 \pm 3,2) \%)$. П'ята частина опитаних $((20,0 \pm 3,3) \%)$ отримала статус особи 3 інвалідністю після травми хребта, ще $(11,3 \pm 2,6) \%-$ внаслідок травматичної ампутації ділянок тіла. Значно рідше причиною були множинні переломи $((6,0 \pm 1,9) \%)$ та термічні чи хімічні опіки $((3,3 \pm 1,5) \%)$.

Опитані особи 3 інвалідністю характеризувались доволі високим рівнем освіти (рис. 2), що підкреслює соціально-економічне значення проблеми. У кожного п'ятого була вища $((21,9 \pm 3,4) \%)$, а в кожного другого - середня спеціальна 


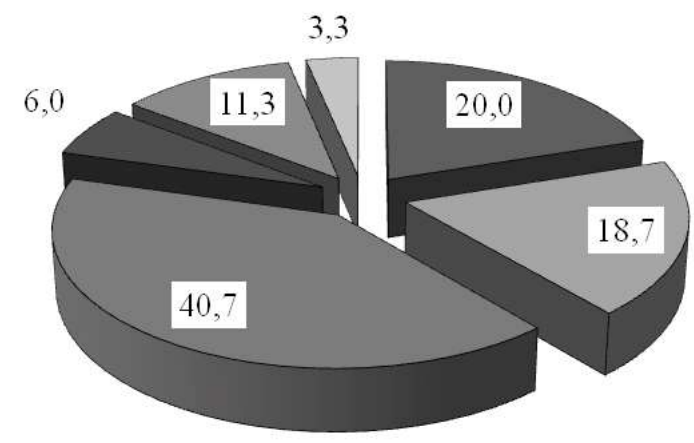

口переломхребта
口переломкісток верхніх кінщівок
口перелом кісток нгжніх кінщівок
口переломив декількох ділянках тіла
口травматична ампутація ділянок тіла
口термічні та хімічні опіки, відмороження

Puc. 1. Структура причин інвалідності внаслідок травм опорно-рухового апарату.

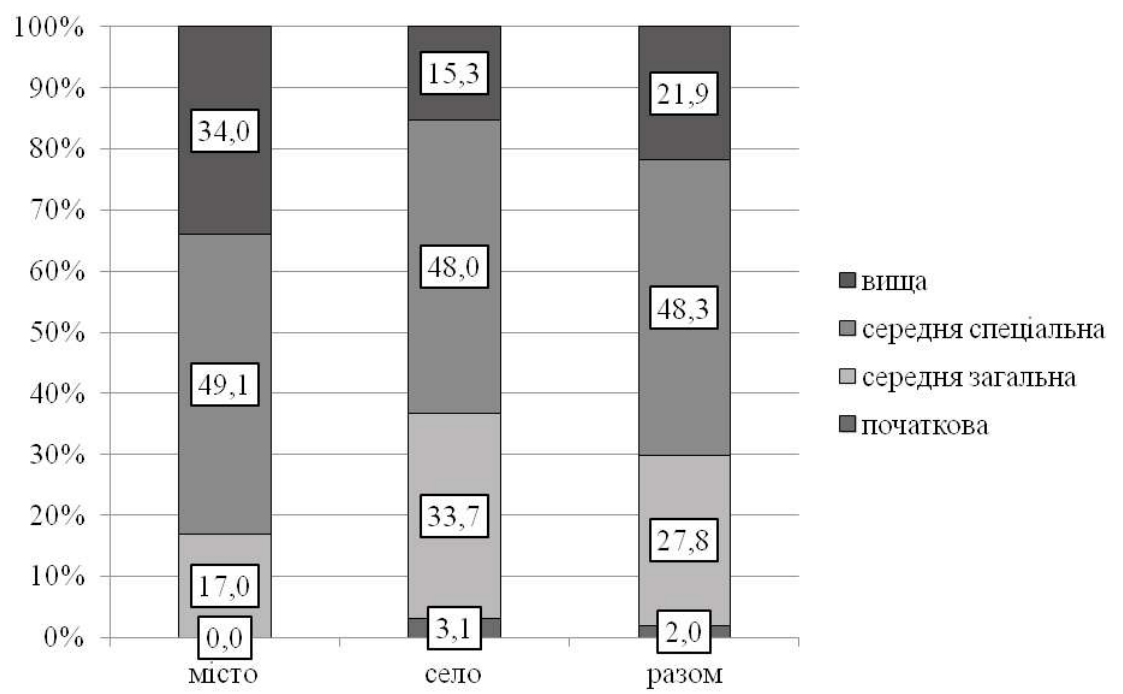

Рuc. 2. Поділ опитаних осіб з інвалідністю після травм опорно-рухового апарату за рівнем освіти.

$((48,3 \pm 4,1) \%)$ освіта. Менше третини респондентів $((27,8 \pm 3,6) \%)$ мали середню загальну освіту і лише $(2,0 \pm 1,1) \%$ - нижче середньої. При цьому, розглянуті показники не відрізнялись ні за віком, ні за гендерною ознакою (p>0,05), але загалом нижчий рівень освіти, цілком зрозуміло, був у сільських мешканців $(p<0,05)$. Так, серед них удвічі рідше траплялися респонденти 3 вищою освітою $((15,3 \pm 3,6)$ \% проти $(34,0 \pm 6,5)$ \% серед жителів міст), і вдвічі частіше - 3 середньою загальною освітою $((33,7 \pm 4,8) \%$ проти $(17,0 \pm 5,2) \%$ відповідно).

Встановлено, що практично половина респондентів $((47,7 \pm 4,1) \%)$, незалежно від статі, віку та місця проживання ( $>0,05)$, відносила себе за рівнем матеріального благополуччя до бідних верств населення (рис. 3). Ще половина $((49,7 \pm 4,1) \%)$ оцінювала свій добробут як середній, поодинокі опитані $((2,6 \pm 1,3) \%)$ - як вище середнього, і жоден - як високий.

Вивчення об'єктивного рівня матеріального добробуту показало, що на момент опитування у половини респондентів середньомісячний дохід на одного члена сім'ї був нижчим від прожиткового мінімуму - $(50,0 \pm 4,2) \%$. Тобто, реальні дані збігаються з результатами самооцінки респондентів і вказують на небезпеку низького доступу осіб з інвалідністю після травм опорно-рухового апарату до необхідної медичної допомоги та, як наслідок, неадекватного лікування і запізнілого початку реабілітації. Тим більше, що зі слів опитаних отримана травма, яка стала причиною встановлення групи інвалідності, значно вплинула на рівень матеріального забезпечення і сумарно більш ніж у половини випадків $((51,0 \pm 4,1) \%)$, незалежно від віку та статі опитаних $(p>0,05)$, суттєво погіршила його.

У той же час, виявлено, що більшою мірою відчували негативний вплив інвалідності на фінансове становище сільські мешканці $((61,2 \pm 4,9) \%$ порівняно із $(32,1 \pm 6,4) \%$ серед містян, $p<0,01)$. Очевидно, це може бути зумовлено тим, що основна діяльність сільських мешканців впродовж життя пов'язана головним чином із фрізичною працею і цілком логічно, що фракт отримання травми негативно впливає на можливість працювати. Крім цього, у сільського населення значно нижчі можливості додаткових заробітків чи адекватного до їх стану працевлаштування, ніж у містах. 


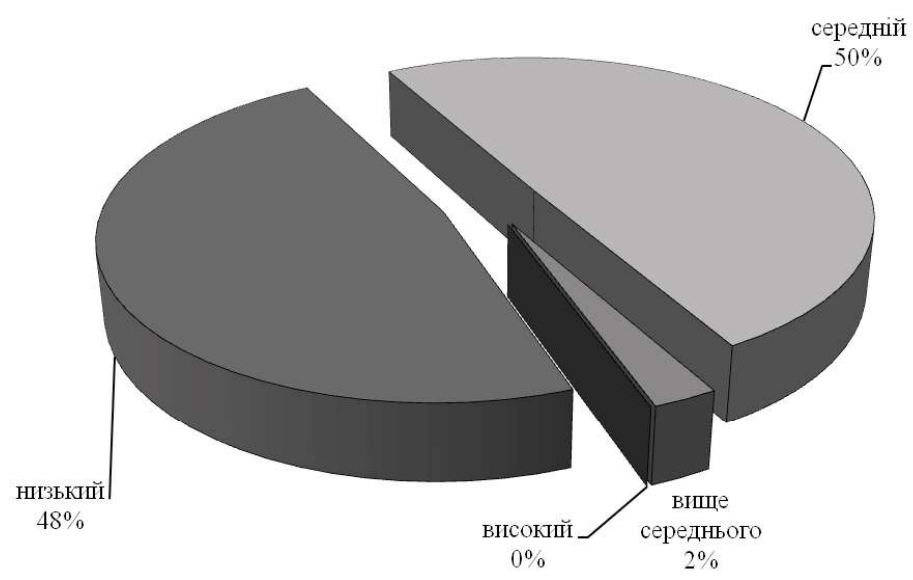

Рис. 3. Самооцінка опитаними особами з інвалідністю після травм опорно-рухового апарату свого рівня матеріального добробуту.

3 огляду на сказане зрозуміло, чому приблиз-

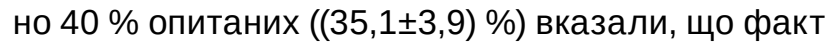
встановлення групи інвалідності дозволив їм частково поліпшити своє матеріальне становище за рахунок нарахування пенсії. Хоча частка тих, кому це суттєво вплинуло на добробут, незначна $((13,2 \pm 2,8) \%)$, а більшість респондентів $((51,7 \pm 4,1) \%)$ взагалі не розглядала цю подію як можливість поліпшити власні доходи.

Аналіз характеру професійної діяльності респондентів показав, що більшість 3 них за фрахом представники фрізичної праці $((59,6 \pm 4,0) \%)$, а кожен четвертий $((25,8 \pm 3,6) \%)$ - розумової. Проте $(14,6 \pm 2,9)$ \% опитаних зазначили, що ніколи не працювали.

Характер професійної діяльності опитаних відрізнявся за гендерною ознакою $(p<0,05)$ - частка жінок, представниць переважно розумової діяльності, удвічі перевищувала таку серед чоловіків $((39,1 \pm 7,2)$ \% проти $(20,0 \pm 3,9) \%)$. Відповідно серед жінок було менше представниць фрізичної праці - $(45,7 \pm 7,3)$ \% проти $(65,7 \pm 4,6) \%$.

Суттєво відрізнявся поділ респондентів за профресією і залежно від місця проживання $(p<0,05)$. Підтверджено, що частка сільських мешканців, основна професійна діяльність яких пов'язана 3 фрізичною працею, значно більша, аніж аналогічний показник серед міського населення $((66,3 \pm 4,8) \%$ проти $(47,2 \pm 6,9) \%)$. На противагу цьому, лише п'ята частина осіб, які проживають у сільській місцевості, за фрахом були представниками переважно розумової праці, що майже удвічі менше, аніж частка таких серед містян $((19,4 \pm 4,0) \%$ проти $(37,7 \pm 6,7) \%)$.

3 іншого боку, питома вага осіб без попереднього стажу будь-якої діяльності серед респондентів - сільських мешканців практично така ж, як і серед жителів міст $((14,3 \pm 3,5) \%$ i $(15,1 \pm 4,9) \%$ відповідно).

Встановлено, що фракт встановлення групи інвалідності негативно вплинув і на фрактичну зайнятість опитаних (рис. 4). Більшість 3 них $((51,7 \pm 4,1) \%)$ змушена була внаслідок цього залишити будь-яку роботу, третя частина $((27,8 \pm 3,6) \%)$ змінила вид діяльності або місце роботи, і тільки кожен десятий $((11,9 \pm 2,6) \%)$ не змінював місце роботи.

Більше постраждали від інвалідності після травм опорно-рухового апарату сільські мешканці та представники чоловічої статі $(p<0,05)$. Так, серед жителів сіл після встановлення інвалідності змогли залишитися на попередньому місці роботи лише $(6,1 \pm 2,4) \%$, порівняно $3(22,6 \pm 5,7) \%$ респондентів із числа містян.

Серед осіб з інвалідністю чоловічої статі аналогічний показник становив $(7,6 \pm 2,6)$ \% проти $(21,7 \pm 6,1) \%$ серед жінок.

Отримані дані цілком узгоджуються із уже показаним фрактом переважної професійної приналежності чоловіків і мешканців сіл до представників фрізичної праці, виконання якої стає неможливим після отриманої травми.

Це припущення підтверджується й тим, що абсолютна більшість $((87,4 \pm 3,0) \%)$ респондентів скаржилися, що змушені були змінити або залишити будь-яку трудову діяльність внаслідок незадовільного стану здоров'я, а ще кожен десятий $((10,1 \pm 2,8) \%)$ вважав, що його попереднє робоче місце не адаптоване для особи 3 інвалідністю.

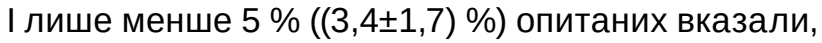
що причиною змін у зайнятості стало погіршення ставлення працедавця чи колег.

На існування суттєвої проблеми із працевлаштуванням осіб з інвалідністю в країні вказує й те, що серед респондентів, які змушені були внаслідок неї змінити або залишити будь-яку трудову діяльність, майже кожен другий $((41,7 \pm 4,0) \%)$ визнав, що має потребу в працевлаштуванні, знову більш акцентовано серед сільських мешканців $((46,9 \pm 5,0) \%$ проти $(32,1 \pm 6,4)$ \% серед жителів міст, $p<0,05)$ і представників чоловічої статі $((48,6 \pm 4,9)$ \% проти $(26,1 \pm 6,5) \%$ серед жінок $з$ ін- 


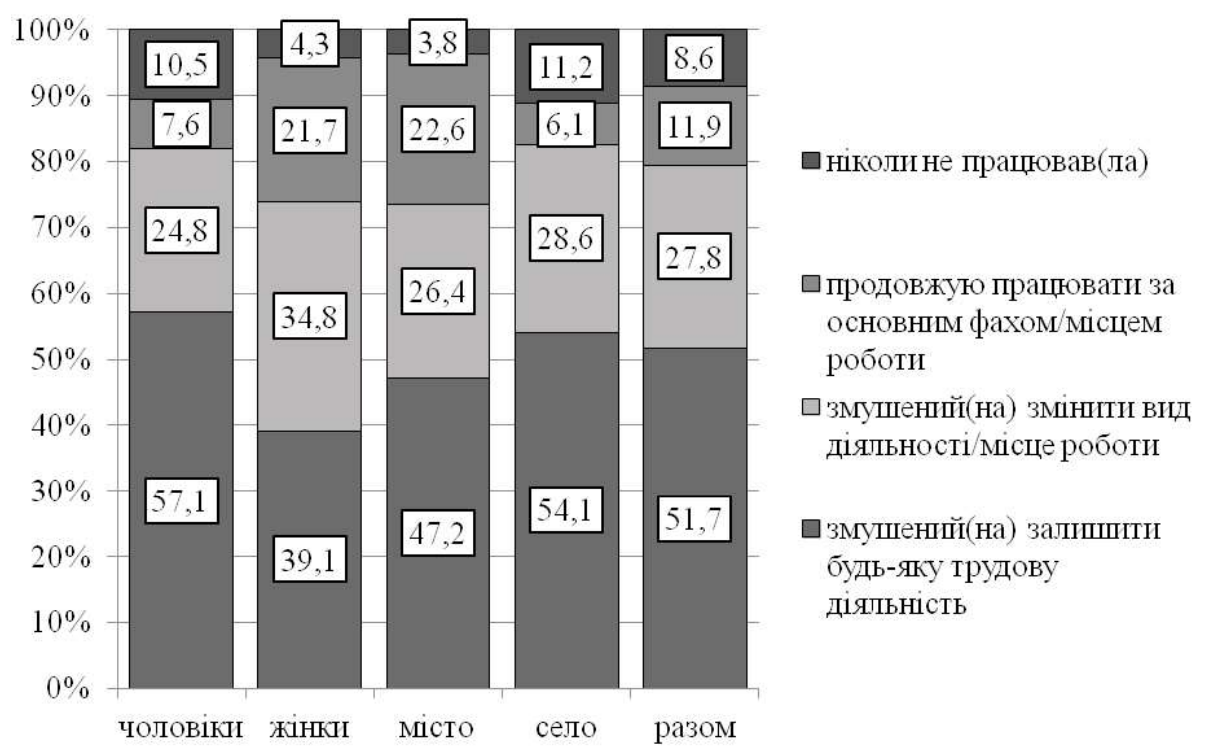

Рuc. 4. Характеристика змін у зайнятості респондентів після встановлення їм інвалідності.

валідністю, р<0,05). При цьому вражає, що половина таких респондентів $((50,8 \pm 6,3) \%)$ навіть не знала, куди звертатися за допомогою із працевлаштування.

\section{Висновки}

1. Встановлено, що найбільш вразливими щодо інвалідності після травм опорно-рухового апарату є чоловіки (69,5 \%), мешканці сільської місцевості (64,9 \%), зайняті у професіях із фрізичним характером праці (66,3-65,7\%).

2. Виявлено, що наявність інвалідності після травм опорно-рухового апарату призводить до суттєвого погіршення матеріального добробуту в $(51,0 \pm 4,1) \%$ таких осіб, більш виражено серед

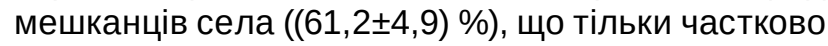
покривається матеріальною допомогою у межах системи соціального захисту $((43,5 \pm 7,3) \%)$.
3. Показано, що інвалідність після травм опорно-рухового апарату та пов'язане із нею погіршення стану здоров'я $((87,4 \pm 3,0) \%)$ супроводжується втратою $((51,7 \pm 4,1) \%)$ чи зміною $((27,8 \pm 3,6) \%)$, пошуком $((41,7 \pm 4,0) \%)$ місця роботи, також більш акцентовано серед чоловіків із сільської місцевості.

4. Необхідно удосконалити систему медико-соціальної та профресійної реабілітації осіб з інвалідністю після травм опорно-рухового апарату, зокрема серед чоловіків, зайнятих у сільському господарстві на роботах із фрізичним характером праці.

Перспективи подальших досліджень полягатимуть у розробці науково обґрунтованої моделі удосконалення системи реабілітації осіб з інвалідністю після травм опорно-рухового апарату.

\section{Список літератури}

1. Віжунов О. В. Історичні передумови фрормування поняття «особа з інвалідністю» / О. В. Віжунов // Прикарпатський юридичний вісник. - 2019. - № 1 (4). - С. 58-61.

2. Володіна В. С. Інвалідність і питання доступності / В. С. Володіна, О. О. Виноградов, О. І. Гужва // Педагогіка й сучасні аспекти фрізичного виховання : збірник наукових праць $\mathrm{V}$ Міжнародної науково-практичної конореренції, 17-18 квітня 2019 року. - Краматорськ : ДДМА, 2019. - С. 238-246.

3. Про схвалення Концепції Загальнодержавної програми «Здоров'я 2020: український вимір» : Розпорядження Кабінету Міністрів України від 31 жовтня 2011 р. №1164-р.

4. Панасюк Р. В. Еволюційний погляд на десініцію «інвалідність» / Р. В. Панасюк // Актуальні проблеми психології : збірник наукових праць Інституту психології імені Г. С. Костюка НАПН України. - 2018. - № VII (45). - С. $240-252$.

5. Про реабілітацію осіб з інвалідністю в Україні : Закон України від 6.10.2005 р. № 2961-IV [Електронний ресурс]. Режим доступу : https://zakon.rada.gov.ua/laws/show/2961-15.

6. Соціальний захист населення України в 2019 році. - К. : ДП «Держаналітінформ», 2020.

7. Трегуб П. О. Вплив інвалідності на соціально-економічні аспекти життя осіб з обмеженими можливостями / П. О. Трегуб, Т. Р. Арасланова // Надбання сучасної епідеміології та біостатистики як запорука покращання громадського здоров'я в Україні : матеріали науково-практичної конференції. - Харків : ХНМУ, 2019.

8. Трюхан О. А. Поняття та причини інвалідності як юридичного факту втрати працездатності / О. А. Трюхан // Правове життя сучасної України : у 3 т. : матеріали Міжнар. наук.-практ. конфр. (м. Одеса, 15 трав. 2020 р.) / відп. ред. М. Р. Аракелян. - Одеса : Гельветика, 2020. - Т. 2. - С. 192-195.

9. Forthofer R. N. Biostatistics: A guide to design, analysis, and discovery / R. N. Forthofer, E. S. Lee, M. Hernandez. Amsterdam: Elsevier Inc. - 2007. 
10. Rethinking disability / A. Cieza, C. Sabariego, J. Bickenbach, S. Chatterji // BMC Med. - 2018. - Vol. 16. - P. 14. DOI: https://doi.org/10.1186/s12916-017-1002-6.

11. WHO. Convention on the Rights of Persons with Disabilities: Resolution adopted by the General Assembly. - 2007. Access mode : https://www.refworld.org/docid/45f973632.html.

12. WHO. The global burden of disease: 2004 update. - 2008. - Access mode : https://www.who.int/healthinfo/global_ burden_disease/2004_report_update/en/.

13. $W \overline{H O}$. World report on disability. - 2011. - Access mode : https://www.who.int/publications/i/item/world-report-ondisability.

\section{References}

1. Vizhunov, O.V. (2019). Istorychni peredumovy formuvannia poniattia "osoba z invalidnistiu" [Historical preconditions for the formation of the concept of "person with a disability"]. Prykarpatskyi yurydychnyi visnyk - Prykarpattia Legal Bulletin, 1(4). DOI: https://doi.org/10.32837/pyuv.v1i4(29).395 [in Ukrainian].

2. Volodina, V.S., Vynohradov, O.O., \& Huzhva, O.I. (2019). Invalidnist i pytannia dostupnosti [Disability and accessibility issues]. Pedahohika i suchasni aspekty fizychnoho vykhovannia - Pedagogy and Modern Aspects of Physical Education. Kramatorsk [in Ukrainian].

3. (2011). Kontseptsia Zahalnoderzhavnoi prohramy "Zdorovia 2020: ukrainskyi vymir" №1164-p. [The concept of the National Program "Health 2020: the Ukrainian dimension" No.1164-r.]. [in Ukrainian].

4. Panasiuk, R.V. (2018). Evoliutsiinyi pohliad na definitsiiu "invalidnist" [An evolutionary view of the definition of "disability"]. Aktualni problemy psyholohii - Actual Problems of Psychology, VII(45), 240-252 [in Ukrainian].

5. (2005). Pro reabilitatsiiu osib z invalidnistiu v Ukraini [On rehabilitation of persons with disabilities in Ukraine]. No 2961-IV [in Ukrainian].

6. (2020). Sotsialnyi zahyst naselennia Ukrainy v 2019 rotsi [Social protection of the population of Ukraine in 2019]. Kyiv: DP "Derzhanalitinform" [in Ukrainian].

7. Trehub, P.O., \&Araslanova, T.R. (2019). Vplyv invalidnosti na sotsialno-ekonomichni aspekty zhyttia osib z obmezhenymy mozhlyvostiamy [The impact of disability on the socio-economic aspects of the lives of people with disabilities]. Nadbannia suchasnoi epidemiolohii ta biostatystyky yak zaporuka pokrashchannia hromadskoho zdorovia $v$ Ukraini - Acquisition of Modern Epidemiology and Biostatistics as a Guarantee of Improving Public Health in Ukraine. HNMU. Kharkiv [in Ukrainian].

8. Triukhan, O.A. (2018). Poniattia ta prychyny invalidnosti yak yurydychnoho faktu vtraty pratsezdatnosti [The concept and causes of disability as a legal fact of disability]. Pravove zhyttia suchasnoi Ukrainy - Legal life of modern Ukraine, Odesa: Helvetyka [in Ukrainian].

9. Cieza, A., Sabariego, C., Bickenbach, J., \& Chatterji, S. (2018). Rethinking disability. BMC Med, 16, 14. DOI: https://doi. org/10.1186/s12916-017-1002-6.

10. Forthofer, R.N., Lee, E.S., \& Hernandez, M. (2007). Biostatistics: A guide to design, analysis, and discovery. Amsterdam: Elsevier Inc.

11. (2007). WHO. Convention on the rights of persons with disabilities: Resolution adopted by the General Assembly. Retrieved from: https://www.refworld.org/docid/45f973632.html.

12. (2008). WHO. The global burden of disease: 2004 update. Retrieved from: https://www.who.int/healthinfo/global_ burden_disease/2004_report_update/en/

13. (2011). WHO. World report on disability. Retrieved from: https://www.who.int/publications/i/item/world-report-ondisability.

\section{SOCIO-ECONOMIC CHARACTERISTICS OF PERSONS WITH DISABILITIES AFTER MUSCULOSKELETAL INJURIES}

O. Z. Detsyk, H. Ya. Yukish

Ivano-Frankivsk National Medical University, Ivano-Frankivsk, Ukraine

Purpose: to analyze the socio-economic characteristics of people with disabilities after musculoskeletal injuries.

Materials and Methods. It was conducted a medical and social study on the basis of the Ivano-Frankivsk Bureau of Medical and Social Expertise. A representative sample of 150 people who underwent re-examination due to disability after musculoskeletal injuries was interviewed according to a specially designed author's program. Statistical processing of the obtained material was performed by calculating the frequency of factors per 100 respondents and standard error $( \pm \mathrm{m})$ for frequencies. Testing the null hypothesis was performed by calculating the Pearson chi-square test $(x 2)$.

Methods were used: epidemiological, sociological, biostatistical.

Results. It was found that patients after musculoskeletal injuries most often were assigned to the third group of disability $(75.5 \pm 3.5) \%$, to the second group - $(22.5 \pm 3.4) \%$, and to the first $-(2.0 \pm 1.1) \%$. Its causes were fractures of the lower $(40.7 \pm 4.0) \%$ and upper $(18.7 \pm 3.2) \%$ limbs, spinal injuries $(20.0 \pm 3.3) \%$, traumatic amputation of body parts $(11.3 \pm 2.6) \%$, multiple fractures $(6.0 \pm 1.9) \%$ and thermal or chemical burns $(3.3 \pm 1.5) \%$. Almost all respondents are of working age: up to 30 years $-7.3 \%, 30-39$ years $-31.1 \%, 40-49$ years $-30.5 \%$, $50-59$ years $-30.5 \%, 60$ and older $-0.7 \%$. 
It was found that men (69.5\%), rural residents (64.9\%), employed in occupations with a physical nature of work (66.3-65.7\%) are the most vulnerable to disability after musculoskeletal injuries. Presence of disability after musculoskeletal injuries leads to a significant deterioration in material well-being in (51.0 \pm 4.1$) \%$ of such persons, more pronounced among rural residents $(61.2 \pm 4.9) \%$, which is only partially covered by reimbursement of the state social security system $(43.5 \pm 7.3) \%$. Disability after musculoskeletal injuries and associated deterioration of health $(87.4 \pm 3.0) \%$ is accompanied by loss $(51.7 \pm 4.1) \%$ or change $(27.8 \pm 3.6) \%$, as well as the search $(41.7 \pm 4.0) \%$ for a job, is also more widespread among men from rural areas.

Conclusions. It is necessary to improve the system of rehabilitation of persons with disabilities after injuries of the musculoskeletal system, especially among men employed in agriculture with a physical nature of work.

KEY WORDS: health care organization; disability; rehabilitation; socio-economic factors.

Рукопис надійшов до редакції 05.08.2020 p.

\section{Відомості про авторів:}

Децик Орина Зенонівна - доктор медичних наук, професор, завідувач кафедри соціальної медицини та громадського здоров'я Івано-Франківського національного медичного університету; тел.: +38(050) 373-33-09.

Юкіш Галина Ярославівна - асистент кафедри соціальної медицини та громадського здоров'я Івано-

Франківського національного медичного університету; тел.: +38(095) 555-35-83. 